\title{
The use of PCR-RFLP to genetically distinguish the morphologically close species: Ceriodaphnia dubia Richard, 1894 and Ceriodaphnia silvestrii Daday, 1902 (Crustacea Cladocera)
}

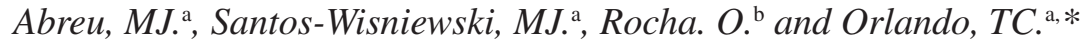 \\ a Department of Biological Science, Federal University of Alfenas - UNIFAL, \\ Rua Gabriel Monteiro da Silva, 714, CEP 37130-000, Alfenas, MG, Brazil \\ ${ }^{b}$ Department of Ecology and Evolutionary Biology, Federal University of São Carlos - UFSCar, \\ CP 676, CEP 13565-905, São Carlos, SP, Brazil \\ *e-mail: tecris@unifal-mg.edu.br \\ Received June 13, 2008 - Accepted March 24, 2009 - Distributed February 28, 2010
}

(With 4 figures)

\begin{abstract}
The cladocerans are important components of planktonic and benthic freshwater and good indicators of the trophic state of water bodies. The morphological taxonomy of many species of Cladocera is considered complex with minor differences separating some species. Nowadays, molecular techniques provide a powerful tool to identify and classify different taxonomical levels, using mainly ribosomal RNA genes (rRNA) as molecular markers. In the present work we performed PCR-RFLP to separate Ceriodaphnia dubia, an exotic species in Brazil and the native species Ceriodaphnia silvestrii, widely distributed in Brazilian freshwater. The RFLP analysis of the ITS1-5.8S-ITS2 region of rRNA genes showed to be different between $C$. dubia and C. silvestrii when using enzymes EcoRI, ApaI and SalI. Thus, the ITS1-5.8S-ITS2 region proved to be a useful molecular marker to differentiate the studied Ceriodaphnia species, which makes the task easier of telling apart species that are morphologically very similar. Also, this methodology might be interesting in determining the distribution of the exotic species C. dubia in Brazilian freshwaters, particularly in cases when $C$. dubia occurs in the absence of $C$. silvestrii, a particularly difficult task for ecologists who are not taxonomy specialists.
\end{abstract}

Keywords: molecular markers, Cladocera, exotic species, DNA extraction, spacer regions.

\section{Utilização do PCR-RFLP para diferenciar geneticamente as espécies Ceriodaphnia dubia Richard, 1894 e Ceriodaphnia silvestrii Daday, 1902 (Crustacea Cladocera)}

\begin{abstract}
Resumo
Os cladóceros são considerados importantes componentes de comunidades bentônicas e planctônicas de água doce e bons indicadores do estado trófico da água. A taxonomia morfológica de muitas espécies de Cladocera é considerada complexa com pequenas diferenças que separam algumas espécies. Atualmente, as técnicas moleculares são consideradas uma ferramenta importante para identificar e classificar diferentes níveis taxonômicos, com a utilização, principalmente, de genes de rRNA como marcadores moleculares. No presente trabalho foi utilizada PCR-RFLP para diferenciar geneticamente Ceriodaphnia dubia, uma espécie exótica no Brasil, e a espécie nativa Ceriodaphnia silvestrii, amplamente distribuída em corpos d'água brasileiros. A análise por RFLP da região ITS1-5.8S-ITS2 dos genes de rRNA mostrou diferenças entre C. dubia e C. silvestrii para os sítios das enzimas de restrição EcoRI, ApaI e SalI. Dessa forma, a região ITS1-5.8S-ITS2 mostrou-se um marcador molecular útil para diferenciar as espécies de Ceriodaphnia estudadas, o que facilita a separação de espécies muito similares morfologicamente. Também, os resultados apresentados parecem ser interessantes na determinação da distribuição da espécie exótica $C$. dubia em corpos d'água brasileiros, principalmente nos casos onde $C$. dubia ocorre na ausência de $C$. silvestrii, uma tarefa difícil para ecologistas não especialistas em taxonomia.
\end{abstract}

Palavras-chave: marcadores moleculares, Cladocera, espécies exóticas, extração de DNA, regiões espaçadoras. 


\section{Introduction}

Cladocerans are important members of freshwater communities, both planktonic and benthic. (Elmoor-Loureiro, 1997). Some species make good indicators of the trophic state of the water bodies in which they occur (Paranaguá et al., 2005) and some genera (eg. Daphnia) have been used as models for ecological investigations, as test-organisms in ecotoxicological studies and more recently in ecological genetics. So far, many details of the life cycle, gene flow and population genetics of cladocerans are known for only a few species (Fonseca and Rocha, 2004; Schwenk et al., 1998). The morphological taxonomy of many species of Cladocera is a complex matter, considering that only small differences separate some species from others. Besides, different morphological forms from the same species of Ceriodaphnia could be related to the presence of predators (Rietzler et al., 2008). However, correct identification at the species level is very important when evaluating biodiversity at infraspecific level or estimating genetic variability of a population (Rocha; Güntzel, 1999). Even when the ecological characteristics of a species are well known, biogeographic studies can be impaired by problems with complex taxonomical affiliations. Nowadays, recently-developed molecular techniques that aim to identify and classify organisms at various taxonomic levels, are a powerful aid to comparative analysis (Schwenk et al., 1998). Ribosomal RNA (rRNA) genes have been widely used as molecular markers for taxonomic purposes. The spacer regions of the repeat unit favour fixation at a higher rate (since they are submitted to a neutral selective pressure) than the gene regions. Therefore the internal transcribed spacers (ITS) regions are rather interesting for studies on taxonomy and identification, because the spacer sequences have revealed intraspecific variation when analysed by RFLP, frequently both in sequence and size (Sollner-Webb and Mougey, 1991; Matioli, 2001).

A cladoceran genus of the family Daphnidae possessing morphologically similar species, which hampers the systematic biology of the group, is Ceriodaphnia (Berner, 1987; Elmoor- Loureiro, 1997). In the present study, two species of Ceriodaphnia were investigated: Ceriodaphnia dubia Richard, 1894, a species considered exotic, in Brazil, which was introduced as a test organism for ecotoxicological investigations (now already colonizing many water bodies) and the native species Ceriodaphnia silvestrii Daday, 1902, widely distributed in Brazilian freshwaters. These species are only distinguishable by details on the proximal pecten of the postabdominal claw, and even among specialists there is uncertainty in telling them apart (ElmoorLoureiro, 1997). The aim of this study was, therefore, to search for molecular markers in order to genetically distinguish the native species $C$. silvestrii (both laboratory cultured clones and specimens found in the Furnas Hydroelectricity Power Plant Reservoir) from the exotic species C. dubia (laboratory grown).
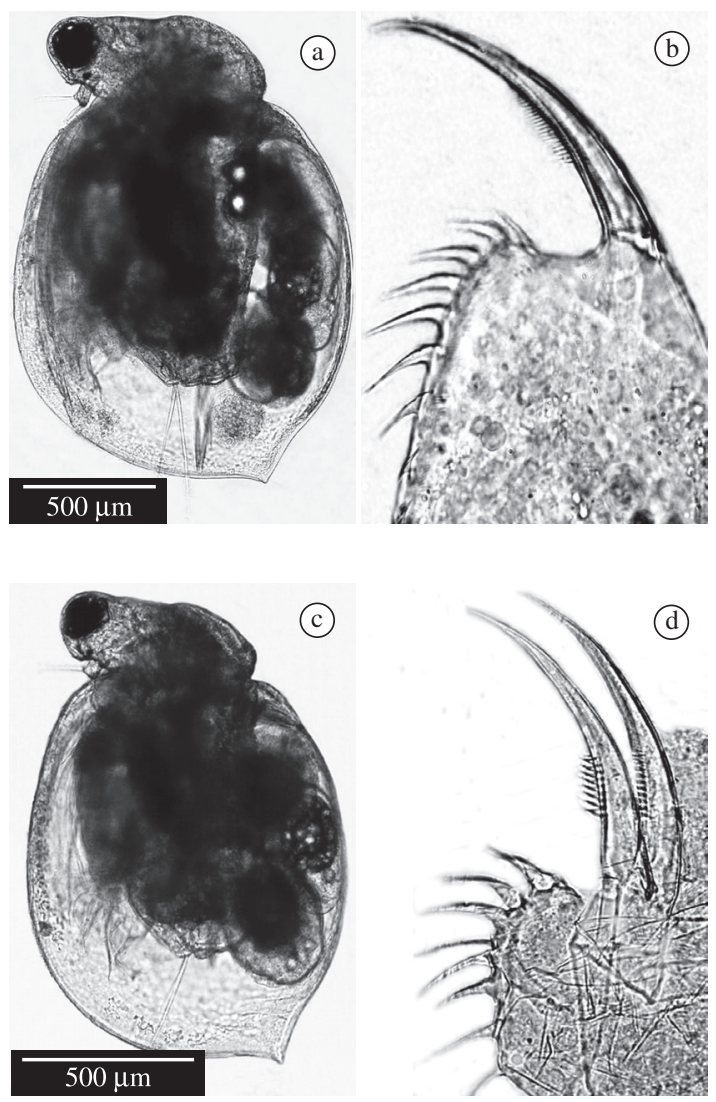

Figure 1. a) General view; b) Proximal pecten of the postabdominal claw of Ceriodaphnia dubia; c) General view and d) Proximal pecten of the postabdominal claws of Ceriodaphnia silvestrii.

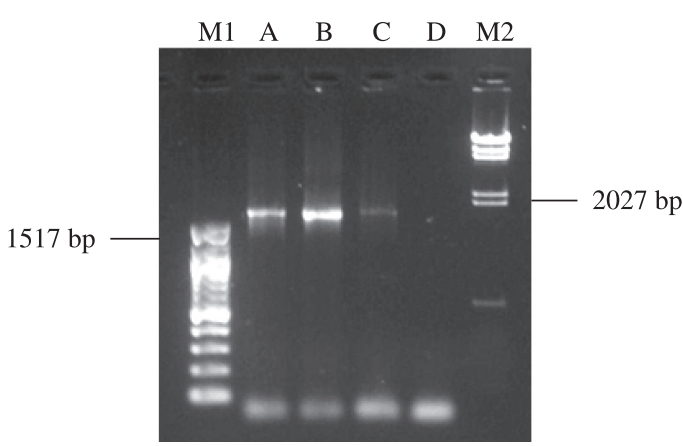

Figure 2. PCR products for the ITS1-5.8S-ITS2 region. M1) Molecular Marker 100 bp BioLabs; A) C. dubia; B) C. silvestrii (culture); C) C. silvestrii (reservoir); D) Negative Control; M2) Molecular marker $\lambda$ HindIII , onto a $1 \%$ agarose gel, ethidium bromide stained.

\section{Material and Methods}

Zooplankton samples were collected in the Furnas Hydroelectricity Power Plant Reservoir by horizontal trawls with a $40 \mu \mathrm{m}$ mesh zooplankton net. Samples 
were preserved in $50 \%$ ethanol to facilitate identification and isolation of individuals under the stereomicroscope in view of their rapid movements when alive. Subsequently, specimens were checked taxonomically by optical microscopy. Cladoceran DNA extraction was carried out with the QIAamp DNA Micro Kit (Qiagen), using a bulk of 150 individuals. The animals were pretreated in order to break down their carapaces: after adding the kit lysing buffer, the material was crushed. After this step, the kit protocol was followed. The polymerisation chain reaction (PCR) was used to amplify the ITS1-5.8S-ITS2 region, in order to search for molecular markers that could discriminate both species. The primers required for the reaction were designed based on rRNA gene sequences found in GenBank: namely DUBIA 181-5'GGAAGTAAAAGTCGTAACAAGG3' (corresponding to the 3 ' end of C. dubia 18S/SSU rRNA gene) and DUBIA 28 5'CGAGGTTCGGTGCTGGGCTCATCC3' (complementary to the 5' end of the 28S/LSU rRNA gene). PCR reactions were performed using $100 \mathrm{ng}$ of genomic DNA, $100 \mathrm{mM}$ Tris- $\mathrm{HCl}, 500 \mathrm{mM} \mathrm{KCl}, 0.8 \%$ Nonidet P40, $1.5 \mathrm{mM} \mathrm{MgCl}_{2}, 100 \mu \mathrm{M}$ dNTPs, 50 pmol each primer and 2 units of Taq Recombinant DNA polymerase (Fermentas, Life Science). The amplification cycles were: $94{ }^{\circ} \mathrm{C}$ for 5 minutes; 30 cycles of $94{ }^{\circ} \mathrm{C}$ for 1 minute, $57{ }^{\circ} \mathrm{C}$ for 1 minute, $72{ }^{\circ} \mathrm{C}$ for 2 minutes; and a final extension at $72{ }^{\circ} \mathrm{C}$ for 10 minutes. After sizefractioning of products in agarose gels, each product was purified (Wizard ${ }^{\circledR}$ SV gel and PCR clean-up system - Promega) and cloned into pGEM-T Easy Vector Kit (Promega), which has a plasmid of 3015 bp as cloning vector and a cleavage site for each of the restriction enzymes used in the analysis (in the linker), including two EcoRI sites flanking the PCR product cloning site.

\section{Results}

The specimens of $C$. dubia and $C$. silvestrii used in the present study were distinguishable by details on the proximal pecten of the postabdominal claw as seen in Figure 1 The PCR reaction resulted in a product of approximately $1900 \mathrm{bp}$ in size for the ITS1-5.8S-ITS2 region of the rRNA genes of $C$. dubia and $C$. silvestrii, obtained from laboratory cultures and isolated from Furnas Reservoir (Figure 2). EcoRI digestions of each recombinant plasmids released PCR product for each cladoceran species (Figure 3, lanes EcoRI A, B and C). Also, the recombinant plasmids obtained were submitted to the double digestion with the enzymes EcoRI/SalI, EcoRI/ApaI and ApaI/SalI (Figure 3), in order to determine the position of each site in the ITS1-5.8S-ITS2 region of each species. The restriction fragments length polymorphism (RFLP) pattern was detected to be very different between $C$. dubia (Figure 3, lanes A) and C. silvestrii (Figure 3, lanes B and C), however, the cleavage pattern was the same for $C$. silvestrii cultured in the laboratory and the organisms isolated from the Reservoir (Figure 3, lanes $\mathrm{B}$ and $\mathrm{C}$, respectively).

A scheme of the restriction map for each species is shown in Figure 4. Therefore, the RFLP analysis of the cloned PCR products showed the three enzymes analysed could be useful as molecular markers to differentiate $C$. silvestrii and $C$. dubia, since the latter species has two cleavage sites for the enzyme SalI, no restriction site for the enzyme ApaI and different site position for the enzyme EcoRI (Figure 4).

\section{Discussion}

From these results it may be concluded that the Qiagen kit for DNA extraction (QIAamp DNA Micro Kit) was

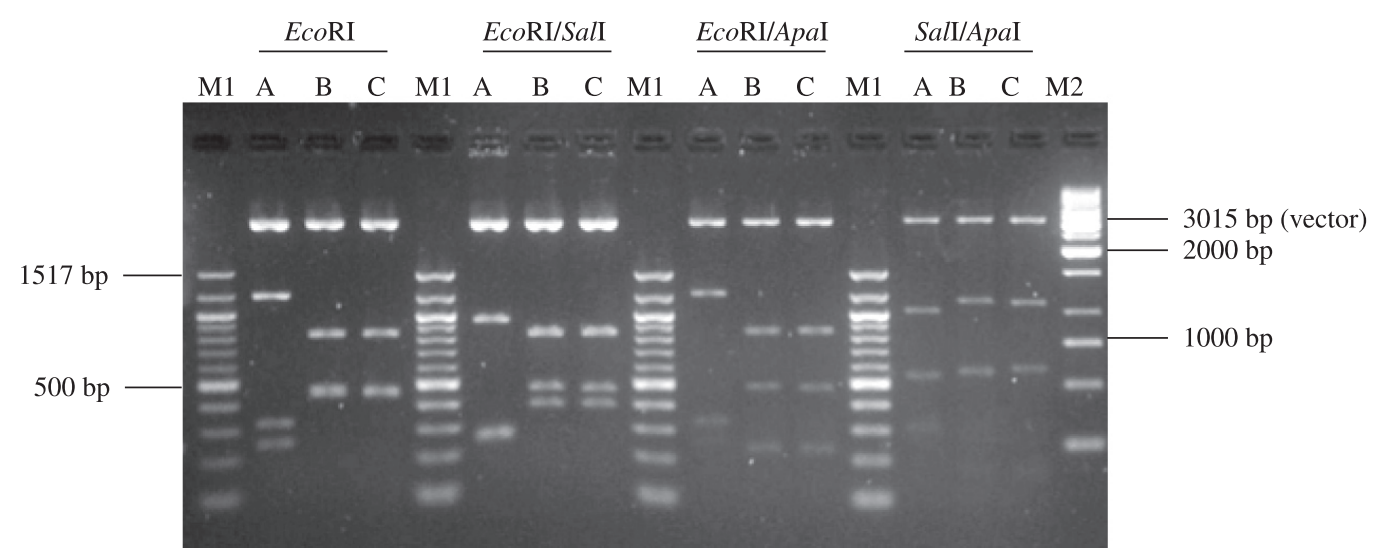

Figure 3. RFLP analysis of recombinant plasmids containing the ITS1-5.8S-ITS2 region. M1) Molecular marker $100 \mathrm{bp}$ (BioLabs); A) C. dubia; B) C. silvestrii (culture); C) C. silvestrii (reservoir). M2) Marker $1 \mathrm{~Kb}$ (Invitrogen), onto a $1.3 \%$ agarose gel, ethidium bromide stained. 


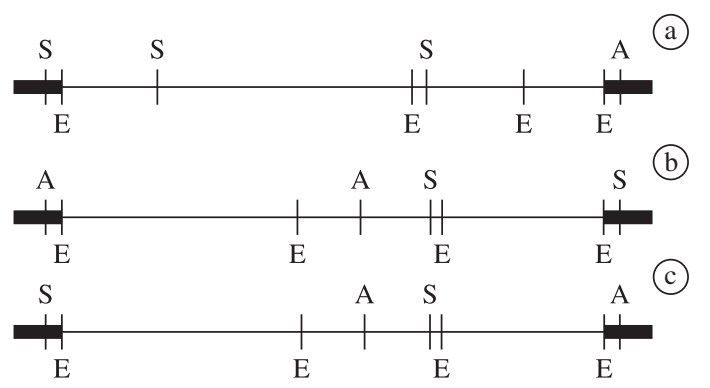

Figure 4. Scheme of enzyme site position of ITS1-5.8S-ITS2 region. a) C. dubia b) C. silvestrii (culture); c) C. silvestrii (reservoir). E, EcoRI; S, SalI; A, ApaI. Bold lines represent plasmid ends in the pGEM-T Easy Vector (Promega), which products of both $C$. silvestrii ITS1-5.8S-ITS2 region were inserted in plasmids in opposite directions in $\mathrm{b}$ and $\mathrm{c}$.

effective for the DNA extraction from cladocerans with sufficient quality and enough amplification in the PCR reaction to find molecular markers for taxonomic purposes. The present study is the first succeeding to isolate and characterise the complete ITS1-5.8S-ITS2 region of the rRNA genes of cladocerans of the Ceriodaphnia genus, showing that its size is similar to that found in several species of the Daphnia genus, which is approximately 1900 bp (Taylor, Sprenger and Ishida, 2005). By comparing this region it is possible to assert that the species Ceriodaphnia silvestrii and Ceriodaphnia dubia, which are morphologically very similar, are actually two genetically distinct species. Additionally, the same pattern of restriction was found for the individuals of the species $C$. silvestrii analysed (both from lab cultures and from the Furnas Reservoir), corroborating the hypothesis that all of them belonged to that species.

It can therefore be concluded that the region ITS15.8S-ITS2 is a good molecular marker for differentiating the species of Ceriodaphnia studied, considering that it includes both conserved regions (such as the $5.8 \mathrm{~S}$ region), and less conserved regions such as the ITS-1 and ITS-2 spacers, facilitating the task of distinguishing species that are morphologically very similar. This methodology might be very useful in determining the distribution of the exotic species C. dubia in Brazilian freshwater, particularly when $C$. dubia occurs in the absence of $C$. silvestrii, and it is not possible to make a ready morphological comparison of the two, a particularly difficult task for ecologists who are not taxonomy specialists.
Acknowledgements - To the Hydrobiology and Hatchery Station of Furnas Centrais Elétricas S.A., P. \& D. ANEEL Program and FINEP (nº 0990/01) for financial support.

\section{References}

BERNER, DB., 1987. Significance head and carapace pores in Ceriodaphnia (Crustacea Cladocera). Hydrobiologia, vol. 145, p. $75-84$.

ELMOOR-LOUREIRO, LMA., 1997. Manual de Identificação de Cladóceros Límicos do Brasil. Brasília: Universa. 156p.

FONSECA, AL. and ROCHA, O., 2004. The life cycle of Ceriodaphnia silvestrii Daday, 1902, a neotropical endemic species (Crustacea, Cladocera, Daphnidae). Acta Limnologica Brasiliensia, vol. 16, p. 319-328.

MATIOLI, SR., 2001. Biologia molecular e evolução. Ribeirão Preto: Holos.

PARANAGUÁ, MN., NEUMANN-LEITÃO, S., NOGUEIRAPARANHOS, JD., SILVA, TA. and MATSUMURA-TUNDISI, T., 2005. Cladocerans (Branchiopoda) of a tropical estuary in Brazil. Revista Brasileira de Biologia = Brazilian Journal of Biology, vol. 65, p. 107-115.

ROCHA, O. and GÜNTZEL, AM. 1999. Crustáceos branquiópodos. In: ISMAEL, D., VALENTI, WC., MATSUMURA-TUNDISI, T. and ROCHA, O. Biodiversidade do estado de São Paulo, Brasil: invertebrados de água doce. vol. 4. São Paulo: FAPESP. p. 107-120.

SCHWENK, K., SAND, A., BOERSMA, M., BREHM, M., MADER, E., OFFERHAUS, D. and SPAAK, P., 1998. Genetic markers, genealogies and biogeographic patterns in the Cladocera. Aquatic Ecology, vol. 32, p. 37-51.

SOLLNER-WEBB, B. and MOUGEY, EB., 1991. News from the nucleolus: rRNA gene expression. Trends in Biochemical Sciences, vol. 16, p. 58-62.

RIETZLER, AC., ROCHA, O., ROCHE, KF. and RIBEIRO, MM., 2008. Laboratory demonstration of morphological alterations in Ceriodaphnia cornuta Sars (1885) fa rigaudi induced by Chaoborus brasiliensis Theobald (1901). Revista Brasileira de Biologia = Brazilian Journal of Biology, vol. 68, no. 2, p. 453-454.

TAYLOR, DJ., SPRENGER, HL. and ISHIDA, S., 2005. Geographic and phylogenetic evidence for dispersed nuclear introgression in a daphniid with sexual propagules. Molecular Ecology, vol. 4, p. 525-37. 